\title{
Assessment of Atrial Natriuretic Peptide (ANP) and Lipid Profile for Hypertension Patients in Thi-Qar province, Iraq
}

Haneen Kadhim Zaid

Department of Biology/

Collage of Sciencel

University of Thi-Qar

Nasseryia/Iraq

haneenkadhim1994@gmail.com

\author{
Khalid G. Al-Fartosi \\ Department of Biology/ \\ Collage of Sciencel \\ Iraq University of Thi-Qar, Iraq \\ Nasseryia/Iraq
}

\section{https://doi.org/10.32792/utq/utjsci/v8/1/8}

\begin{abstract}
The present study was designed to assessment of atrial natriuretic peptide (ANP) and lipid profile of patients with hypertension in Thi-Qar province, Iraq. The sample included 70 patients, who were attending Al- Nasiryiah heart center during the period from February 2019 to June 2019, with 30 healthy as a control group. The results showed a significant increase. $(\mathrm{P} \leq \mathbf{0 . 0 5})$ of systolic blood pressure (SBP) and diastolic blood pressure (DBP) in hypertension patients compared with the control group. The level of atrial natriuretic peptide (ANP) showed a significant increase $(P \leq 0.05)$ in patients compared with control group. Also the result indicated a significant increase $(P \leq 0.05)$ of $T C, T G, L D L$ and VLDL in patients compared with the control, while there was a significant decrease in HDL of patients compared with the control.
\end{abstract}

Keywords - hypertension, Atrial natriuretic peptide (ANP), lipid profile

\section{INTRODUCTION}

Hypertension is characterized as a systolic blood pressure ( SBP) greater than $140 \mathrm{mHg}$ or a diastolic blood pressure (DBP) greater than $90 \mathrm{mmHg}$; the diagnosis is based on an average of 2 or more readings per 2 or more visits after initial screening (Holm $e t$ al., 2006) . Hypertension is a major health problem, particularly because the symptoms are not apparent. Most people get hypertension without being aware of it. Modifier factors such as obesity, overweight measured by body mass index, visceral adiposity measured by waist circumference, increased age, are now well known to be correlated with the high prevalence of hypertension (Dibby, 2015). High blood pressure is one of the most common world disorders which cause many effects on human body (Al-Hamdani, 2010). It is the main risk factor for cardiovascular disease, congestive cardiac failure, stroke and endstage of kidney disease (Casey et al., 2006). Hypertension is one of manifestation of metabolic syndrome (Hassan et al., 2016).

Atrial natriuretic peptide (ANP) is a potent diuretic, vasorelaxant hormone, which is synthesized predominantly in the cardiac atria. In response to intravascular volume expansion and blood pressure (BP) elevation, this peptide controls sodium-water balance (Kato et al., 2000). Under normal hemodynamic conditions, it is predominantly synthesized, stored, and secreted in a regulated fashion by modified myocytes of the cardiac atria. However, in patho-physiological conditions of hemodynamic overload (in congestive heart failure, ventricular synthesis of the peptide) it is reactivated and contributes significantly to the circulating pool of the peptide (Ahmed et al., 2012).

The majority of hypertensive patients are diagnosed with elevated lipid rates such as raised cholesterol, triglycerides and/or reduced lipoproteins in high density (Lamina and Okoye, 2012). Although a specific pattern of dyslipidemia was not identified in people with high blood pressure, several studies have shown that cholesterol, triglycerides and other fatty proteins are abnormal in people with high blood pressure (Osuji et al., 2012). Dyslipidemia is more common in untreated hypertensive patients than healthy individuals and lipid profile values were increased as blood pressure in pattern of dyslipidemia and has been consistently reported among hypertensive patients (Murtadha, 2017). Also hypertension is known to be related with change of lipid metabolism which causes increase of lipid levels and progression of cardiovascular disease (CVD) ( Chales et al., 2012). The present study aimed to assessment of ANP level and lipid profile of patients with hypertension in Thi-Qar province, Iraq.

\section{MATERIALS AND METHODS}

\section{A. Study Population}

The target population of this study was 70 patients (male 40 and female 30) who were already diagnosed as hypertension patients were attending the AL-Nasiriyah Heart Center in Thi- Qar province, Iraq during the period from February 2019 to June 2019 with age ranged between (30 - 80 years) . A control group was composed of 30 (male 16 and female 14) healthy with the same age range.

\section{B. Blood pressure Measurement}

Blood pressure was measured using a device sphygmomanometer.

\section{Blood Sample}

Blood samples were obtained by venipuncture from patients and control group. The blood sample was dispensed in a plain tube, and left for 15 minutes at room temperature to clot. Then, it was centrifuged at $3000 \mathrm{rpm}$ for 10 minutes to collect serum and kept 
in the freezer $\left(-20^{\circ} \mathrm{C}\right)$ until use unless used immediately to analyze biochemical parameters.

\section{Atrial natriuretic peptide assay}

The Atrial natriuretic peptide levels were analysed using commercially available Human ANP ELISA Kit from elabscience company, This ELISA kit uses the Competitive-ELISA principle. The micro ELISA plate provided in this kit has been pre-coated with Human ANP. During the reaction, Human ANP in the sample or standard competes with a fixed amount of Human ANP on the solid phase supporter for sites on the Biotinylated Detection $\mathrm{Ab}$ specific to Human ANP. Excess conjugate and unbound sample or standard are washed from the plate, and Avidin conjugated to Horseradish Peroxidase (HRP) are added to each microplate well and incubated. Then a TMB substrate solution is added to each well. The enzyme-substrate reaction is terminated by the addition of stop solution and the color change is measured spectrophotometrically at a wavelength of $450 \mathrm{~nm} \pm 2 \mathrm{~nm}$. The concentration of Human ANP in the samples is then determined by comparing the OD of the samples to the standard curve.

\section{E. Determination of serum lipid profile}

The lipid profile (total cholesterol, triglycerides, HDL, LDL and VLDL) was determined in the serum using COBAS INTEGRA systems.

\section{F. Statistical analysis}

Statistical analysis was done using the software SPSS version 23.0.The results were expressed as mean \pm standard deviations (mean \pm SD ) with LSD. One way ANOVA-test was used to compare parameters in different studied groups. P-values $(\mathrm{P} \leq$ $0.05)$

\section{Results and discussion}

\section{A. Blood pressure}

The results showed a significant increase $(\mathrm{P}<0.05)$ of systolic blood pressure (SBP) $(148.33 \pm 15.12)$ and diastolic blood pressure (DBP) $(96.18 \pm 7.22)$ in hypertension patients compared with control group (124.48 $\pm 6.46,81.03 \pm 4.89)$ (table 1).

Table 1: Level of systolic blood pressure (SBP) and diastolic blood pressure (DBP) in patients and control group

\begin{tabular}{|c|c|c|}
\hline Proups & $\begin{array}{c}\text { SBP } \\
(\mathrm{mmHg}) \\
\text { Mean } \pm \text { SD }\end{array}$ & $\begin{array}{c}\text { DBP } \\
(\mathrm{mmHg}) \\
\text { Mean } \pm \text { SD }\end{array}$ \\
\hline Control & $124.48 \pm 6.46^{\mathrm{b}}$ & $81.03 \pm 4.89^{\mathrm{b}}$ \\
\hline Patients & $148.33 \pm 15.12^{\mathrm{a}}$ & $96.18 \pm 7.22^{\mathrm{a}}$ \\
\hline LSD & 3.23 & 1.72 \\
\hline
\end{tabular}

The different letters refers a significant different at $\mathrm{P} \leq 0.05$ Systolic blood pressure (SBP) and diastolic blood pressure (DBP) of male and female hypertension patients increased significantly $(\mathrm{P} \leq 0.05)$ compared with the control group (table 2$)$.

Table 2: Systolic blood pressure (SBP) and diastolic blood pressure (DBP) of male and female patients with control group.

\begin{tabular}{|l|c|c|c|}
\hline gender & Groups & $\begin{array}{c}\text { SBP(mmHg) } \\
\text { Mean } \pm \text { SD }\end{array}$ & $\begin{array}{c}\text { DBP(mmHg) } \\
\text { Mean } \pm \text { SD }\end{array}$ \\
\hline Male & Control & $122.15 \pm 5.30^{\mathrm{b}}$ & $80.16 \pm 5.10^{\mathrm{b}}$ \\
\cline { 2 - 4 } & Patients & $147.13 \pm 12.22^{\mathrm{a}}$ & $98.15 \pm 8.19^{\mathrm{a}}$ \\
\cline { 2 - 4 } & LSD & 3.52 & $2.55^{\mathrm{b}}$ \\
\hline Female & Control & $124.08 \pm 5.90^{\mathrm{b}}$ & $81.01 \pm 4.81^{\mathrm{b}}$ \\
\cline { 2 - 4 } & Patients & $145.18 \pm 11.89^{\mathrm{a}}$ & $94.20 \pm 7.15^{\mathrm{a}}$ \\
\cline { 2 - 4 } & LSD & 4.05 & 2.63 \\
\hline
\end{tabular}

-The different letters refers a significant different at $\mathrm{P} \leq 0.05$

For most high blood pressure patients the cause is unknown. This is classified as primary or essential hypertension. More than $90 \%$ of high blood pressure patients have primary hypertension. Primary hypertension cannot be healed, but it can be managed with appropriate treatment (including improvements in lifestyle and medication). Genetic factors may play a significant role in primary hypertension growth. This form of hypertension tends to evolve gradually over several years (Olin and Pharm, 2018), while less than $10 \%$ of patients with high blood pressure have secondary HT. The most common cause of secondary HT is associated with kidney impairment such as chronic kidney disease (CKD) or renovascular disease. This form of high blood pressure tends to appear suddenly and often causes higher blood pressure than primary HT (Saseen, 2014; CDC, 2015). many previous epidemiological studies have revealed that older age, obesity,smoking, longer duration of hypertension, higher baseline blood pressure level, excessive salt consumption, diabetes, most of these factors perse contribute to blood pressure elevation (Cai et al., 2017)

\section{B. Atrial natriuretic peptide (ANP)}

The results showed a significant increase $(\mathrm{P} \leq 0.05)$ of atrial natriuretic peptide (ANP) level in hypertension patients (185.03 \pm 20.13$)$ compared with control group $(98.62 \pm 9.15)$ (table 3).

Table 3: level of atrial natriuretic peptide (ANP) in patients and control group

\begin{tabular}{|c|c|}
\hline Parameters & $\begin{array}{c}\text { ANP (Pg Mean } \pm \text { SD } \\
\text { Groups }\end{array}$ \\
\hline Control & $98.62 \pm 9.15^{\text {b }}$ \\
\hline Patients & $185.03 \pm 20.13^{\text {a }}$ \\
\hline LSD & 4.38 \\
\hline
\end{tabular}

-The different letters refers a significant different at $\mathrm{P} \leq 0.05$

Table (4) show atrial natriuretic peptide (ANP) of male and female hypertension patients increased significantly $(\mathrm{P} \leq 0.05)$ compared with the control group.

Table 4: level of atrial natriuretic peptide (ANP) of male and female patients with control group.

\begin{tabular}{|l|c|c|c|}
\hline Parameters & Groups & Male (Mean \pm SD) & $\begin{array}{c}\text { Female (Mean } \pm \\
\text { SD) }\end{array}$ \\
\hline \multirow{3}{*}{$\begin{array}{l}\text { ANP } \\
(\mathrm{pg} \mid \mathrm{ml})\end{array}$} & Control & $100.86 \pm 13.01^{\mathrm{b}}$ & $97.89 \pm 12.32^{\mathrm{b}}$ \\
\cline { 2 - 4 } & Patients & $189.01 \pm 28.13^{\mathrm{a}}$ & $186.96 \pm 26.57^{\mathrm{a}}$ \\
\cline { 2 - 4 } & L.S.D & 8.15 & 8.86 \\
\hline
\end{tabular}

-The different letters refers a significant different at $\mathrm{P} \leq 0.05$

ANP is excreted from the heart. It binds in the kidney and blood vessels to its receptor, and promotes salt excretion, lowers blood volume, and relaxes the vessel. This endocrine system binds the heart and the kidney to maintain a perfect balance between electrolytes and body fluid (Zhou et al., 2009). The possible reason for the elevated ANP levels is that the increased atrial stretch, resulting from volume overload, increases atrial peptides release rates. With the atrial problem of changes in left ventricular function induced by hypertension, this is likely to be a strong combined trigger for the release of auricular peptides (Nicholls et al., 1987). The elevated levels of ANP in hypertensive subjects can be associated with a tendency towards decreased kidney sodium excretion, either as a result of hereditary kidney abnormality or as a result of high blood pressure. This could cause sodium retention and thus increase compensatory mechanisms to excrete the sodium 
excess. Most patients with essential hypertension, however, either have normal or low blood volume. (Tarazi, 1983).

\section{Lipid profile level}

The result indicated a significant increase $(\mathrm{P} \leq 0.05)$ of $\mathrm{TC}, \mathrm{TG}$, LDL and VLDL in patients of hypertension $(213.53 \pm 19.20$, $193.19 \pm 15.25,137.40 \pm 8.63,38.19 \pm 3.20$ ) compared with the control group $(158.96 \pm 13.58, \quad 113.30 \pm 12.25, \quad 77.78 \pm 4.37$, $22.66 \pm 2.11$ ), while there was a significant decrease in HDL of patients(37.94 \pm 6.15$)$ compared with the control group(58.53 \pm 9.10$)$ (table 5).

Table 5: Level of lipid profile (TC, TG, HDL, LDL and LDL) in hypertension patients and control group.

\begin{tabular}{|l|c|c|c|}
\hline \multicolumn{1}{|c|}{$\begin{array}{c}\text { Groups } \\
\text { Parameters }\end{array}$} & $\begin{array}{c}\text { Control } \\
\text { Mean } \pm \text { SD }\end{array}$ & $\begin{array}{c}\text { Patients } \\
\text { Mean } \pm \text { SD }\end{array}$ & LSD \\
\hline TC (mgldl) & $158.96 \pm 13.58^{\text {b }}$ & $213.53 \pm 19.20^{\text {a }}$ & 4.67 \\
\hline TG (mgldl) & $113.30 \pm 12.25^{\mathrm{b}}$ & $193.19 \pm 15.25^{\text {a }}$ & 3.88 \\
\hline LDL (mgldl) & $77.78 \pm 4.37^{\text {b }}$ & $137.40 \pm 8.63^{\text {a }}$ & 1.92 \\
\hline HDL (mgldl) & $58.53 \pm 9.10^{\text {a }}$ & $37.94 \pm 6.15^{\text {b }}$ & 2.17 \\
\hline $\begin{array}{l}\text { VLDL } \\
\text { (mgldl) }\end{array}$ & $22.66 \pm 2.11^{\text {b }}$ & $38.19 \pm 3.20^{\text {a }}$ & 0.76 \\
\hline
\end{tabular}

-The same letters refers non-significant different at $\mathrm{P} \leq 0.05$

-The different letters refers a significant different at $\mathrm{P} \leq 0.05$

The results indicated a significant increase $(\mathrm{P} \leq 0.05)$ in $\mathrm{TC}$, TG , LDL and VLDL in patients of male and female patients compared with the control group, while the HDL showed a significant decrease in male and female patients compared with control group as (table 6).

Table 6: Lipid profile (TC, TG, HDL, LDL and LDL) of male and female hypertension patients with control group.

\begin{tabular}{|c|c|c|c|}
\hline Parameters & Groups & Male Mean \pm SD & Female Mean \pm SD \\
\hline \multirow[t]{3}{*}{ TC(mgldl) } & Control & $159.06 \pm 11.30^{b}$ & $156.43 \pm 11.03^{b}$ \\
\hline & Patients & $205.19 \pm 13.33^{\mathrm{a}}$ & $203.93 \pm 11.23^{\mathrm{a}}$ \\
\hline & LSD & 4.85 & 4.80 \\
\hline \multirow[t]{3}{*}{ TG(mgldl) } & Control & $108.23 \pm 11.09$ & $103.20 \pm 10.55$ \\
\hline & Patients & $193.15 \pm 16.09$ & $183.20 \pm 15.58$ \\
\hline & LSD & 5.14 & 5.74 \\
\hline \multirow[t]{3}{*}{ LDL(mgldl) } & Control & $82.31 \pm 4.81^{b}$ & $79.59 \pm 3.95^{b}$ \\
\hline & Patients & $132.72 \pm 4.55^{\mathrm{a}}$ & $132.74 \pm 4.96^{a}$ \\
\hline & LSD & 1.40 & 1.27 \\
\hline \multirow[t]{3}{*}{ HDL(mgldl) } & Control & $55.10 \pm 6.33^{a}$ & $56.20 \pm 6.03$ \\
\hline & Patients & $33.84 \pm 5.56^{b}$ & $34.55 \pm 5.08$ \\
\hline & LSD & 2.21 & 2.41 \\
\hline \multirow[t]{3}{*}{ VLDL(mgldl) } & Control & $21.65 \pm 2.22$ & $20.64 \pm 2.11$ \\
\hline & Patients & $38.63 \pm 3.22^{a}$ & $36.64 \pm 3.12$ \\
\hline & LSD & 1.01 & 1.15 \\
\hline
\end{tabular}

-The different letters refers a significant different at $\mathrm{P} \leq 0.05$

The association between hyperlipidemia and hypertension has been shown in several previous studies. An excessive dietary intake of saturated fats, cholesterol and other calorie sources and subsequent lipid profile disruption leading to hypertriglyceridemia and hypercholesterolemia are related to obesity and hypertension In a study Brown, 2000 confirmed the association between several factors including BMI, serum cholesterol, HDL and hypertension (Ghooshchi et al., 2014). Hypertension is considered to be associated with lipid metabolism alterations that give rise to serum lipid and lipoprotein levels abnormalities.It has also been documented that the presence of hyperlipidaemia makes the prognosis in hypertensive patients significantly worse (Osuji et al., 2012). High total blood cholesterol level increase the risk of many large vascular complications such as coronary artery disease (CHD) and stroke (Albucher et al., 2000). The study by Akuyam et al. (2009) In both hypertensive patients and normotensive controls, a positive and significant serum TC relationship with systolic and diastolic blood pressure was found in. High total cholesterol levels may be attributed to a number of causes including stress, increased intake of animal fat, lack of physical activity and genetic factors.

\section{Conclusions}

The present study indicated increase of atrial natriuretic peptide (ANP) in hypertension patients and show a positive association between hypertension and serum lipid profile included triglycerides, total cholesterol, LDL cholesterol levels and VLDL. High fats may be due to eating large amounts of nutritional fat, lack of physical activity and weight gain.

\section{References}

Ahmed, Feroz.; Nahida, Tabassum. and Saima Rasool. (2012). 'Regulation of Atrial Natriuretic Peptide (ANP) and Its Role in Blood Pressure'. International Current Pharmaceutical Journal 1(7): 176-79.

Akuyam, S A.; Aghogho U B.; Aliyu, I. S. and Bakari, A G. (2009). Serum total cholesterol in hypertensive Northern Nigerians . Int J Med and Med Sci; $1: 73-78$.

Albucher, J F.; Ferrieres, J.; Ruidavets, J B.; GuiraudChaumeil, B.; Perret, B P. and Chollet, F.(2000). Serum lipids in young patients with ischaemic stroke: a case-control study. J Neurol Neurosur Ps; $69: 29-33$.

Al-Hamdani, I. H. (2010). Estimation of serum uric acid, urea and creatinine in essential hypertensive patients. Tikrit Med. J., 16(1):152-158.

Brown, C.D.; Higgins, M.; Donato, K.A.; Rohde, F.C.; Garrison, R. and Obarzanek, E .(2000). Body mass index and the prevalence of hypertension and dyslipidemia. Obes Res. Dec; 8(9):605-19.

Casey, P. E.; Philips, A. C.; Shapiro, S. and Ngugen. P. (2006). Controlling high blood pressure. Perm. J., 10 (2):13-16.

Chales, U. O.; Emeka, G. O.; Emmanuel, I.O. and Gladys, I. A - (2012). Serum lipid profile of newly diagnosed hypertensive patients in Nnewi, South East Nigeria. Int. J. Hypertension, 12:714.

Cai, Anping; Yingqing Feng. and Yingling Zhou.(2017). 'A Comprehensive Review of an Unmet Public Health Issue: Resistant Hypertension'. Clinical and Experimental Hypertension 39(2): 101-7.

CDC: high blood pressure [Internet]. Centers for Disease Control and Prevention; c2015. [updated 2014 Oct 29, cited 2015 Jan 26]. Available from: http://www.cdc.gov/bloodpressure/index.htm

Dibby, H. J. (2015). Blood group relationship with hypertension : AL-Qadisiya Medical Journal. 11(20), 7-12.

Ghooshchi, Golnoosh, Mahdi Masoomian, Mohammad Sarafraz Yazdi, and Mona Pour Ramezan. (2014). 'Evaluation of the Lipid Profile of Hypertensive Patients Compared to NonHypertensive Individuals Article History': Patient Saf Qual Improv 2(Md): 5-7.

Holm, Stephen Wilford.; Larry L. Cunningham.; Eric Bensadoun, and Matthew J. Madsen.(2006). 'Hypertension: Classification, Pathophysiology, and Management during 
Outpatient Sedation and Local Anesthesia'. Journal of Oral and Maxillofacial Surgery 64(1): 111-21.

Hassan, E. A.; Al-Zuhairi, W. S. and Ahmed, M .A. (2016) Serum cortisol and BMI in chronic disease and increased early cardiovascular disease. Baghdad Sci. J.,13(2):399-406.

Kato, N.; Sugiyama, T.; Morita, H.; Nabika, T.; Kurihara, H.; Yamori, Y. and Yazaki, Y. (2000). 'Genetic Analysis of the Atrial Natriuretic Peptide Gene in Essential Hypertension'. Clinical Science 98(3): 251-58.

Lamina, S. and Okoye, G. C. (2012) . Therapeutic effect of a moderate intensity interval training program on the lipid profile in men with hypertension: A randomized controlled trial. Nigerian Journal of Clinical Practice. 15 : 42-47.

Nicholls,M. G.; Espiner, E. A.; Ikram, H.; Crozier, I. G. and Richards, A. M. (1987). Atrial natriuretic peptide in human hypertension. European Heart Journal 8 \{Supplement B), 123-128.

Murtadha, Jinan Hussein. (2017). 'Levels of Serum Lipid Profile and Kidney Function Tests in Iraqi Hypertensive Patients: Duration Effect Study'. Baghdad Science Journal 14(2): 363-70.
Olin, Bernie R, and D Pharm. (2018). 'Hypertension: The Silent Killer : Updated JNC-8 Guideline Recommendations'.

Osuji, Charles U.; Emeka G. Omejua.; Emmanuel I. Onwubuya, and Gladys I. Ahaneku. (2012). 'Serum Lipid Profile of Newly Diagnosed Hypertensive Patients in Nnewi, South-East Nigeria'. International Journal of Hypertension 2012.

Saseen JJ, MacLaughlin. (2014). Hypetension. In: DiPiro JT, Talbert RL, Yee GC, Matzke GR, Wells BG, Posey LM,. Pharmacotherapy: A pathophysiologic approach. 9th ed. New York: McGraw-Hill Medical; Chapter 3.

Tarazi, R.C.( 1983). The haemodynamics of hypertension. In: Genest J, Kuchel O, Hamet P, Cantin M, eds Hypertension 2nd ed. New York: McGraw Hill: 15-42.

Zhou, Yiqing., Jingjing, Jiang., Yujie, Cui., and Qingyu, Wu. (2009). 'Corin, Atrial Natriuretic Peptide and Hypertension'. Nephrology Dialysis Transplantation 24(4): 1071-73. 